Katarzyna Wochna, Agnieszka P. Jurczyk, Wojciech Krajewski ${ }^{1}$, Jarosław Berent

\title{
Nagły zgon z powodu hipertermii złośliwej podczas znieczulenia ogólnego
}

\author{
Z Katedry i Zakładu Medycyny Sądowej UM w Łodzi \\ Kierownik: prof. dr hab. n. med. J. Berent \\ 1 Z Zakładu Anestezjologii i Intensywnej Terapii Medycznej, \\ Instytut „Centrum Zdrowia Matki Polki” w Łodzi \\ Kierownik: dr hab. n. med. prof. nadzw. W. Krajewski
}

W prezentowanej pracy autorzy przedstawiają przypadek hipertermii złośliwej. Omawiana jest sprawa zgonu 4-letniego chłopca, który pod opieką rodziców zgłosił się na leczenie stomatologiczne w znieczuleniu ogólnym. Początkowo zabieg przebiegał prawidłowo, jednakże nieoczekiwanie wystąpiły powikłania w postaci zaburzeń rytmu serca, wzrostu temperatury ciała i sztywności mięśni, charakterystyczne dla hipertermii złośliwej. Pomimo przeprowadzonej akcji resuscytacyjnej i pomocy zespołu pogotowia ratunkowego, pacjent zmarł.

Słowa kluczowe:

opinia sądowo-lekarska,

hipertermia złośliwa, znieczulenie ogólne

\section{WSTĘP}

Hipertermia złośliwa to bardzo rzadka choroba uwarunkowana genetycznie, dziedziczona w sposób autosomalny dominujący [1, 2, 3]. Zdarza się raz na kilka - kilkanaście, a nawet kilkadziesiąt tysięcy znieczuleń [3] i może mieć charakter śmiertelny [1, 2]. Charakteryzuje ją niezwykle szybki wzrost temperatury ciała podczas zabiegów przeprowadzanych w znieczuleniu ogólnym, zwłaszcza z użyciem wziewnych środków halogenowych i chlorku sukcynylodwucholiny (suksametonium) [1, 2, 4]. Jest to bardzo groźne schorzenie, może prowadzić do zgonu, jednak współcześnie śmiertelność z powodu wystąpienia hipertermii nie przekracza 10\% [1, 2]. Zmniejszenie śmiertelności wiąże się z szybkim podaniem dantrolenu sodu [5] i wdrożeniem intensywnej terapii [6]. Wcześniej śmiertelność nieleczo- nej hipertermii złośliwej wynosiła powyżej 70-80\% [7].

Do wystąpienia tej choroby może dojść po podaniu leków z bardzo wielu grup: anestetyków dożylnych - ketaminy, anestetyków wziewnych - halotanu, izofluranu, enfluranu, fluroksenu, desfluranu, środków zwiotczających mięśnie szkieletowe - suksametonium, deksametonium, galaminy, d-tubokuraryny, leków sympatykomimetycznych, leków nasercowych - glikozydów naparstnicy, wapnia, a także w hiperkapnii lub w stanie nasilonego stresu [1, 2, 3].

Nieprawidłowa, wewnątrzkomórkowa dystrybucja jonów wapnia to najważniejszy czynnik w patogenezie hipertermii złośliwej. Jony te przez kanały wapniowe patologicznie napływają do sarkoplazmy [8], a to zaburza funkcjonowanie struktur wewnątrzkomórkowych. Gwałtownie narasta kwasica mleczanowa, do krążenia przedostają się produkty rozpadu komórek, takie jak wapń, fosfor, potas, fosfokinaza kreatyniny, mioglobina, zaś stężenie katecholamin wzrasta [1, 2].

Określenie grupy predysponowanej do reakcji hipertermicznej bazuje na wywiadzie, badaniu klinicznym i zaliczeniu do grupy ryzyka: chorzy z wybranymi chorobami układu mięśniowo-szkieletowego (miopatia central core), miotonią wrodzoną i dystrofią Duchenne'a, epizody hipertermii złośliwej w rodzinie, niewyjaśnione zgony podczas zabiegów operacyjnych i znieczulenia w rodzinie, wystąpienie gorączki lub ciemnego moczu po zabiegu operacyjnym u pacjenta $[1,2,3]$.

Wczesnymi objawami hipertermii złośliwej są: sztywność mięśni, tachykardia, sinica, wzrost Pet $\mathrm{CO}_{2}$ (ilość dwutlenku węgla obecna w wydychanym powietrzu), wzmożona potliwość. Do objawów póź- 
nych zalicza się: wzrost temperatury, obniżenie ciśnienia, arytmię, kwasicę metaboliczną, zaburzenia elektrolitowe, rabdomiolizę i DIC, czyli zespół rozsianego wykrzepiania wewnątrznaczyniowego $[1,2,3$, 5, 9]. Temperatura ciała dochodzi nawet do 43-44 st. C, z szybkością wzrostu 1 st. C na 5 minut, jednak na chorobę tę wskazać już może wzrost ciepłoty o 1-2 st. C na godzinę.

Przy podejrzeniu wystąpienia hipertermii złośliwej należy natychmiast zaprzestać podawania anestetyków i sukcynylocholiny [6, 9], wentylować chorego tlenem i podać dantrolen sodu [10, 11] 2,5 mg/kg mc dożylnie (do ustąpienia objawów i dawki całkowitej $10 \mathrm{mg} / \mathrm{kg} \mathrm{mc}$ ), włączyć leki antyarytmiczne (z wyłączeniem blokerów kanału wapniowego), podać wodorowęglan sodu, ochładzać fizycznie, monitorować funkcje życiowe $[1,2,5,6]$. Dantrolen to lek z wyboru [3, 6, 11], zmniejsza napięcie mięśni, jednocześnie odwracając procesy patologiczne zachodzące w mięśniach w przebiegu hipertermii złośliwej [3]. Jest to jednak lek drogi, o stosunkowo krótkim terminie przydatności, więc nie wszystkie jednostki przeprowadzające zabiegi znieczulenia ogólnego nim dysponują. W Polsce, w związku z niezwykle rzadkim występowaniem tego powikłania, nie istnieją ogólnie przyjęte zasady normujące dostępność tego leku. W praktyce zakłada się, iż anestezjolog wykonujący znieczulenia winien wiedzieć, który najbliższy ośrodek dysponuje tym lekiem, by w razie potrzeby zwrócić się do niego o udostępnienie tegoż. Należy dodać, że dantrolen, by spełnił swe zadanie, powinien być podany maksymalnie w ciągu 30 minut od wystąpienia niepożądanych objawów.

\section{OPIS PRZYPADKU}

W sierpniu 2007 roku rodzice zgłosili się ze swoim synkiem, w wieku 3 lat i 10 miesięcy, na zaplanowany zabieg stomatologiczny w znieczuleniu ogólnym. Dziecko miało liczne ubytki próchnicowe, jak również korzenie zębów mlecznych wymagające ekstrakcji. Próby leczenia stomatologicznego podejmowane były wcześniej w kilku gabinetach, jednak bezskutecznie, wobec negatywnej postawy pacjenta i braku współpracy z jego strony ze stomatologiem. W przeddzień zabiegu pacjent został skonsultowany, a rodzice wyrazili zgodę na planowany zabieg. Wywiad ogólny został zebrany, odpowiednia ankieta dotycząca stanu zdrowia dziecka wypełniona przez matkę. Wobec zdobytych danych nie istniały przeciwskazania do znieczulenia ogólnego. Podczas badania przedmiotowego stwierdzono obrzęk policzka prawego i zalecono antybiotyk. Dnia następnego ok. godziny 9:15 pacjenta poddano znieczuleniu ogólnemu, ordynując wymienione leki anestetyczne: Dormicum, Sewofluran, Suksametonium w dawce $1 \mathrm{mg} / \mathrm{kg} \mathrm{mc}$, tlen, podtlenek azotu oraz przeciwbólowo Ketonal, ponadto kroplówkę z glukozą. Odbyło się leczenie zachowawcze zębów 61, 63, 64, 65 oraz wykonano ekstrakcję zębów 53, 52, 51, 62 i 84. W trakcie trwania zabiegu, po około 45 minutach, pojawiły się zaburzenia rytmu serca oraz odnotowano wzrost temperatury do 37,4 st. C. Podano Ksylokainę, zaburzenia rytmu ustąpiły, jednak czynność pracy serca uległa zwolnieniu. Sięgnięto więc po Atropinę, jednak efekt terapeutyczny utrzymał się zaledwie kilka chwil. Saturacja krwi zaczęła maleć, lekarz anestezjolog zauważył sztywność mięśni kończyn dolnych i nieanatomiczne ułożenie stóp pacjenta. W tym czasie temperatura ciała osiągnęła poziom 40 st. C, chłopca schładzano zimnymi okładami, doszło do zatrzymania akcji serca. Anestezjolog zaczął podejrzewać hipertermię złośliwą, wezwano pogotowie ratunkowe i rozpoczęto czynności resuscytacyjne. Kontynuował je zespół pogotowia ratunkowego, jednakże wobec ich nieskuteczności, o godzinie 11:25 stwierdzono zgon dziecka. Przeprowadzona sądowo-lekarska sekcja zwłok oraz wyniki badań dodatkowych pozwoliły ustalić, iż zgon nastąpił w wyniku wstrząsu, do którego doszło najprawdopodobniej na tle hipertermii złośliwej.

\section{OMÓWIENIE}

W opisanym przypadku wywiad ogólny, zebrany od rodziców, nie dawał podstaw do podejrzewania hipertermii złośliwej, jak również nie stanowił wskazań do wdrożenia rozszerzonej diagnostyki lub też zastosowania działań profilaktycznych w tym kierunku przed samym zabiegiem stomatologicznym. Materiał dowodowy (dokumentacja medyczna, zeznania świadków) ujawnia, iż wprowadzenie do znieczulenia, jego przebieg, jak i samo znieczulenie do godziny 10:00 przebiegało bez powikłań, kiedy to wystąpiły zaburzenia rytmu serca, wzrost temperatury ciała oraz sztywność mięśni. Materiał 
dowodowy nie wskazuje na wystąpienie objawu prodromalnego gorączki złośliwej, jakim jest szczękościsk po podaniu suksametonium [3, 12]. W przypadku, gdy do jego zaistnienia dochodzi, może to uniemożliwić intubację pacjenta [14]. Przebieg schorzenia u dziecka był bardzo gwałtowny i powikłany szybkim zatrzymaniem krążenia, co praktycznie uniemożliwiło skuteczne leczenie.

Według oceny biegłych, zabieg stomatologiczny został przeprowadzony prawidłowo, zgodnie z przyjętymi zasadami. Postępowanie anestezjologiczne w kwestii doboru leków i rodzaju znieczulenia było dopuszczalne dla tego typu zabiegów. Chlorek sukcynylodwucholiny to lek coraz rzadziej stosowany, ze względu na działania uboczne, lecz dopuszczony do obrotu i stosowania w lecznictwie. Zastrzeżenie biegłych wzbudziło jednak postępowanie anestezjologa po wystąpieniu powikłań w trakcie znieczulenia. Mianowicie, lekarz, pomimo podejrzenia, że ma do czynienia z hipertermią złośliwą, nie podjął próby zdobycia leku, stosowanego w tego typu przypadkach (Dantrolen). Niezwłoczne podjęcie próby uzyskania brakującego leku i wdrożenie terapii mogły zwiększyć szanse pacjenta na przeżycie. Zaniechanie tej próby naraziło go na bezpośrednie niebezpieczeństwo utraty życia lub ciężkiego uszczerbku na zdrowiu, zakładając, iż istniałyby realne możliwości dostarczenia tego leku przed wystąpieniem nagłego zatrzymania krążenia, a miato to miejsce o godzinie 10:30. Biorąc pod uwagę opis przebiegu choroby, podanie Dantrolenu już po epizodzie zatrzymania krążenia nie dawało realnej szansy na uratowanie życia poszkodowanego. Należy uwzględnić również to, że Dantrolen nie jest lekiem podawanym profilaktycznie przed zabiegiem u osób, które nie należą do grupy ryzyka wystąpienia hipertermii złośliwej, gdyż sam generuje ryzyko wystąpienia objawów niepożądanych.

W toku prowadzonego śledztwa uzyskano informację, iż w dniu zgonu dziecka gabinet stomatologiczny, w którym odbywał się zabieg, nie posiadał na stanie ww. leku, zaś zgodnie z opinią krajowego konsultanta anestezjologii, rezerwa tego leku była zabezpieczona na terenie dwóch jednostek Akademii Medycznej, jednak nikt nie skontaktował się z nimi tego feralnego dnia, w celu uzyskania medykamentu.

Prokuratura wydała postanowienie o wszczęciu śledztwa w sprawie nieumyślnego spowodowania śmierci dziecka, tj. o czyn z art. 155 k.k., wobec faktu, iż zgromadzony materiał dowodowy wskazywał na uzasadnione podejrzenie jego popełnienia. W toku przedmiotowego śledztwa przesłuchano licznych świadków, zgromadzono obszerną dokumentację lekarską oraz dopuszczono dowód z opinii biegłych z zakresu medycyny sądowej Uniwersytetu Medycznego w Łodzi. Ostatecznie prokurator przedstawił zarzut lekarzowi anestezjologowi z tytułu narażenia dziecka na bezpośrednie niebezpieczeństwo utraty życia albo ciężkiego uszczerbku na zdrowiu, tj. o czyn z art. 160 § 3 k.k. W styczniu 2011 roku sporządzono akt oskarżenia. W styczniu 2012 roku obrońca oskarżonej wnioskował o wydanie wyroku skazującego bez przeprowadzenia postępowania dowodowego i wymierzenie kary 10 miesięcy pozbawienia wolności z warunkowym zawieszeniem jej wykonania na okres 2 lat próby. Oskarżona przyłączyła się do stanowiska swego obrońcy, a prokurator, pełnomocnik oskarżycieli posiłkowych, jak i sami oskarżyciele posiłkowi (rodzice chłopca) nie wnieśli sprzeciwu. Oskarżona przyznała się do popełnienia błędu podczas znieczulania dziecka, w wyniku którego nastąpił jego zgon: wobec pojawienia się $w$ trakcie zabiegu typowych dla hipertermii złośliwej objawów, pomimo wysunięcia podejrzenia o wystąpieniu tej choroby u pacjenta, działając nieumyślnie nie podjęła próby uzyskania dantrolenu sodu. Uznano ją winną popełnienia zarzucanego czynu, który stanowi występek z art. 160 § 3 k.k., na tej podstawie skazano i wymierzono karę 10 miesięcy pozbawienia wolności, warunkowo zawieszając jej wykonanie na okres 2 lat. Sąd uwzględnił bowiem właściwości i warunki osobiste oskarżonej, jej dotychczasowy sposób życia i przebieg kariery zawodowej oraz to, że bardzo silnie przeżyła zdarzenia stanowiące przedmiot postępowania i bezpośrednio po nim porzuciła praktykę lekarską. Po ogłoszeniu wyroku oskarżona przeprosiła oskarżycieli posiłkowych. 


\section{PIŚMIENNICTWO}

1. Stowell K. M.: Malignant hyperthermia: a pharmacogenetic disorder, Pharmacogenomics, 2008, 9: 1657-1672.

2. Gurnaney H., Brown A., Litman R. S.: Malignant hyperthermia and muscular dystrophies, Anesth. Analg., 2009, 109: 1043-1048.

3. Mayzner-Zawadzka E.: Śródoperacyjna hipertermia złośliwa - etiopatogeneza i wybrane zagadnienia kliniczne, Anest. Inten. Ter., 1993, 1-2: 39-43.

4. Bujok G., Staudt-Spychałowicz G., Sitek J.: Nietypowy zespół hypertermiczny u dziecka po anestezji, Anest. Inten. Ter., 1992, 24: 37-39.

5. Hutton D.: Emergency preparedness case study: malignant hyperthermia, Plast. Surg. Nurs., 2012, 32: 80-83.

6. Mayzner-Zawadzka E., Sowiński P.: Postępowanie anestezjologiczne $\mathrm{w}$ zagrażającym zespole hipertermii złośliwej, Anest. Inten. Ter., 1991, 23 : 314-317.

7. Kim D. C.: Malignant hyperthermia, Korean J Anesthesiol., 2012, 63: 391-401.

Adres do korespondencji:

Katedra i Zakład Medycyny Sądowej UM w Łodzi

ul. Sędziowska 18 a

91-303 Łódź

tel. + 48426544536

e-mail:kaj.wochna@gmail.com
8. Correia A. C., Silva P. C., da Silva B. A.: Malignant hyperthermia: clinical and molecular aspects, Rev. Bras. Anestesiol., 2012, 62: 820$-837$.

9. Rybicki Z.: Gorączka złośliwa, Intensywna terapia dorosłych, Makmed, Lublin 2009, 192$-194$.

10. Musselman M. E., Saely S.: Diagnosis and treatment of drug- induced hyperthermia, Am. J. Health Syst. Pharm., 2013, 1: 34-42.

11. Flewellen E. H. i in.: Odpowiedź na podawane dawki dantrolenu u przytomnego człowieka, przesłanki odnośnie postępowania w hipertermii złośliwej, Anest. Inten. Ter., 1985, 1: 79.

12. Gronert G. A. i in.: Złośliwa gorączka wywołana u świń, rola mięśni szkieletowych we wzroście zużycia tlenu, Anest. Reanim. Inten. Ter., 1977, 3: 362.

13. Michalewski W., Szczepański J., Sachajdak-Michalewska Z.: Gorączka złośliwa (Malignant hyperthermia) - podstępne zjawisko okołooperacyjne - ocena sądowo-lekarska po operacji cięcia cesarskiego, Arch. Med. Sąd. Kryminol., 1998, 3-4: 227-232. 